\title{
Study on Learning Style Among College Students' Committee of Kolej Tun Dr. Ismail, Universiti Teknologi Malaysia
}

\author{
Umar AlFaruq Abdul Mutalib ${ }^{1}$, Mohd Noor Azli Ali Khan² \\ ${ }^{1}$ School of Civil Engineering, Faculty of Engineering, Universiti Teknologi Malaysia, 81310 UTM Johor Bahru, Johor, \\ Malaysia \\ ${ }^{2}$ Azman Hashim International Business School, Universiti Teknologi Malaysia, 81310 UTM Johor Bahru, Johor, \\ Malaysia \\ *Corresponding author. Email: m-nazli@utm.my
}

\begin{abstract}
Learning style is one of the most important elements in determining the academic achievement of a university student. This study was conducted to determine the factors that influence the success of the students on the academic achievement of the university. Questionnaire was used to obtain feedback from college students' committee of Kolej Tun Dr. Ismail (KTDI), Universiti Teknologi Malaysia (UTM). The results show that strong determination to success, proper time management completing assignment given are the most important factors in determining student achievement in university. The results of this study suggest that a follow-up study will be conducted in the future and some appropriate programs may be undertaken to improve the achievement of university students. A follow-up study on learning styles needs to be continued to formulate programs that are relevant to current needs as well as to positively impact students' academic achievement.
\end{abstract}

Keywords: Learning style, academic performance, student activities, college students' committee, KTDI

\section{INTRODUCTION}

Academic excellence is one of the indicators and criteria that can be a benchmark for student excellence achievement in higher learning institutions. The excellence of academic achievement can give an idea of the level of understanding and mastery in certain field of knowledge. Students' academic excellence is often associated with various factors that influence the achievement of academic performance. It is one of the important things that need to be highlighted for a better future.

Everyone can score excellence in academic field. Achieving academic excellence is a process that took both formal and informal education. Indeed, education is a limitless process throughout life which consume a lot of commitment and passion. It should be balanced with many aspects such as relationship with creator, public relations, time management skills, learning skills, communication skills, self-management, leadership, morals, personality, selfesteem and determination. However, to achieve excellence in the academic field is not easy and impossible. Various factors need to be taken into account and influence the excellence of a student's academic achievement. Ideally, academic excellence is balanced in line with excellence in other fields. It is simply a balanced, holistic, comprehensive and unbiased achievement.
As we know, individuals have their own personality style, different life experiences and a dynamic family background. The formal education received from preschool to university, style or individual learning patterns will vary. Therefore, this study attempts to examine the factors that influence the achievement of academic performance among students of college students' committee of Kolej Tun Dr. Ismail (KTDI), Universiti Teknologi Malaysia (UTM). Specifically, this study aims to identify factors that influence the success and decline of academic performance so that the follow up actions can be taken.

\section{LITERATURE REVIEW}

The findings of the literature study show that some of the factors uneffeicient learning styles and do not focus on learning styles even its are among the main factors that determine the success or failure of a student [3]. There are several studies that examine the progress of students relating to academic achievements.

A study by [1] on a group of bumiputera students from Faculty of Civil Engineering whom were categorized as excellent students either in academic or lifestyle in the campus environment at UTM. The questionnaire was used to obtain information related to the respondents involved. Analysis was made based on information obtained. From this study, it is found that the academic excellence of a 
student is heavily influenced by a way of life that is balanced in terms of spiritual, physical, emotional and intellectual. Therefore, these lifestyle features need to be applied to a student who wants to excel.

A study by [2] was conducted to determine the relationship between critical thinking skills and Cumulative Grade Points Average (CGPA) among students who take Physics Education programme at UTM. A total of 109 first and fourth year students from Physics Education programme were involved in this study, 26 male students and 83 female students. The age range of them were between 19 and 28 years old. The instrument used in this study was Watson Glaser Critical Thinking Appraisal (WGCTA-A). Pearson$r$ correlation is the main statistic used in this study. The results showed that there was a significant correlation between critical thinking skills with students' CPA at 05 . Interpretation skill is the significant aspect of WGCTA which means to predict students' CGPA compared to the skills to make inferences, follow the assumption, make deduction and evaluation of the argument. Furthermore, the results showed that there was no significant relationship between the years of study and the level of students' critical thinking skills.

Besides that, a study was conducted by [5] aims to see whether there is a significant relationship between learning styles such as motivational style, deep-seated style and surface style with student's motivation and academic achievement. This study involved 118 Pre-Bachelor of Education (PPISMP) students by simple random sampling. The instrument used in this study was a measure of the learning styles of 'The Studying at School Inventory' by Selmes (1987), a measure of motivation that is the selfefficacy dimension of the 'Motivated Strategies for Learning Questionnaire' (MSLQ) by Pintrich et al. (1993) and goal orientation dimensions of 'Goal Inventory Instrument' by Plants (2000). Other than that, the academic achievement of students is based on student grades who take the subject of Social Studies 1 in the PPISMP programme. The findings show that there is a significant positive relationship between motivational learning styles and motivational dimensions which are self-efficacy, learning goals and performance goals. In addition, there is no significant relationship between the motivational learning styles, the surface learning styles and the in-depth learning styles with the students' academic achievement.

Next, the study of [7] aims to identify the pattern of learning styles among students of the Bachelor Degree Programme in Science Education and Education (Physics) at UTM. This study also aims to determine the level of learning style for all respondents according to their academic achievement. A total of 66 respondents were involved in this study. The questionnaire used consists of 44 items that study the learning style that can be seen by 4 dimension namely Active and Reflective, Concrete and Intuitive, Visual and Verbal and Structured and Global. The results of the study show that the pattern of learning style practiced by the respondents Years 2, 3 and 4 is not much different, which is for the Year 2 respondents belong to the Active, Intuitive, Visual and Structured learning features while for Years 3 and 4 respondents they belong to Active, Concrete, Visual and compiled learning features.

Other than that, a study by [4] aims to compare the motives for participating in physical activity (PA) through the different types of co-curricular activities chosen by health sciences undergraduate students at Universiti Sains Malaysia (USM), Malaysia. This study was conducted on university students at USM's Health Campus, who were invited to volunteer and complete two measures: Physical Activity and Leisure Motivation Scale (PALMS), and a demographic form, including the types of co-curricular activities in which the students chose to enrol (sports, uniform and art). The participants involved were 590 students from various range of degree programmes related to the medical and health sciences at USM, Kubang Kerian, Kelantan, Malaysia. The results for the study showed that he students who enrolled in sports co-curricular activities generally showed higher motives of affiliation, appearance and physical condition for participating in PA than other types of co-curricular activities. Besides, the findings can provide further insights into the motives for participating in PA among health sciences students and encouragement for students to integrate PA into their daily routines.

A study by [6] was conducted to see the big influence of a style of leadership on the accreditation of private universities in West Kalimantan. Methods used in this study is the application of qualitative and quantitative approaches together (mix) method. The subject of this study is Private University led the XI in West Kalimantan province, but the research is style leadership as variable free and accreditation institution as the variable bound. The finding shows that there is a close relation between leadership skills and academic performance of the students.

\section{METHODOLOGY}

This study focuses on factors affecting academic achievement among college students' committee of KTDI, UTM. This study is a quantitative study using questionnaire as a research instrument. Questionnaire was used to obtain data and information on respondents 'demographics and factors influencing students' academic achievement. The study was conducted on a sample of college students' committee whom obtained a cumulative grade points average (CGPA) of less than 3.00 , between 3.00 and 3.49 and above 3.49. A total of 33 college students' committee of KTDI, UTM were identified based on the CGPA of semester I session $2018 / 2019$ by using questionnaire. The questionnaire was distributed to respondents on 13 May 2019 which was in semester II session 2018/2019.

In this study, the questionnaire was designed based on the objectives and goals to be achieved. The design of the questions in the questionnaire for this study was based on the initial observation of the lifestyle and the learning style in the campus environment. Data from the questionnaire was collected and analysed using Microsoft Excel software. The results of the analysis are presented in statistical form which are frequency and percentage values to facilitate answer scores. The table is used to describe the results of 
analysis. Based on the analysis, the academic achievement factors can be observed and concluded. 33 questionnaires were answered and recorded as our data. Based on the analysis made on the questionnaire, the discussion on the results of the study is discussed in the next section.

\section{FINDINGS}

Table 1 shows demographic profiles of respondents. A total of 84.80 percent of respondents were second year students and 15.20 percent were third year students. Based on Table 2, 48.50 percent are male and 51.5 percent are female. Other than that, Table 3 shows Cumulative Grade Points Average (CGPA) of respondents which are 30.30 percent for above $3.49,51.52$ percent lies between 3.00 and 3.49 then 18.18 percent below 3.00 .

Table 1: Demographic profiles of respondents

\begin{tabular}{|c|c|c|}
\hline Year & Number & Percentage \\
\hline 2 & 28 & 84.80 \\
\hline 3 & 5 & 15.20 \\
\hline Total & $\mathbf{3 3}$ & $\mathbf{1 0 0}$ \\
\hline
\end{tabular}

Table 2: Respondents based on gender

\begin{tabular}{|c|c|c|}
\hline Gender & Number & Percentage \\
\hline Male & 16 & 48.50 \\
\hline Female & 17 & 51.50 \\
\hline Total & $\mathbf{3 3}$ & $\mathbf{1 0 0}$ \\
\hline
\end{tabular}

Table 3: Cumulative Grade Points Average (CGPA) of respondents

\begin{tabular}{|c|c|c|}
\hline CGPA & Number & Percentage \\
\hline Above 3.49 & 10 & 30.30 \\
\hline $3.00-3.49$ & 17 & 51.52 \\
\hline Below 3.00 & 6 & 18.18 \\
\hline Total & $\mathbf{3 3}$ & $\mathbf{1 0 0}$ \\
\hline
\end{tabular}

Table 4 shows the negative factors affecting academic achievement of students gained CGPA below 3.00 which made up of 6 respondents. Based on 6 students whom got CGPA below 3.00, the major factor was lack of focus in class which is 33.33 percent. Some other factors were lost motivation to study, poor learning environment, negative attitude in classroom and poor time management which each of them is 16.67 percent.

Table 4: Negative factors affecting academic achievement of students gained CGPA below 3.00

\begin{tabular}{|c|c|c|}
\hline Response & Number & Percentage \\
\hline Lack of focus in class & 2 & 33.33 \\
\hline
\end{tabular}

\begin{tabular}{|l|c|c|}
\hline Lost motivation to study & 1 & 16.67 \\
\hline Poor learning environments & 1 & 16.67 \\
\hline $\begin{array}{l}\text { Negative attitude in } \\
\text { classroom }\end{array}$ & 1 & 16.67 \\
\hline Poor time management & 1 & 16.67 \\
\hline \multicolumn{1}{|c|}{ Total } & $\mathbf{6}$ & $\mathbf{1 0 0}$ \\
\hline
\end{tabular}

For Table 5 and Table 6 , the total number of students gained CGPA between 3.0 and 3.49 is 17 . Table 5 shows negative factors affecting academic achievement of students gained CGPA between 3.00 and 3.49. It seems that involvement in other activities was the dominant factor that caused bad influence to the CGPA obtained that holds percent of 17.65 . Besides that, other factors were procrastination behaviors in completing a task, financial problem, lazy attitude being playful and not focus in study and also poor time management share the same percent by 11.76 . Next, the factors of 5.88 were copy the work from other students without study the content, poor learning style, stay in different colleges from classmates and bad peer influences can also affect the students result.

Table 5: Negative factors affecting academic achievement of students gained CGPA between 3.00 and 3.49

\begin{tabular}{|l|c|c|}
\hline \multicolumn{1}{|c|}{ Response } & Number & Percentage \\
\hline $\begin{array}{l}\text { Involvement in other } \\
\text { activities }\end{array}$ & 3 & 17.65 \\
\hline $\begin{array}{l}\text { Procrastination behaviours } \\
\text { in completing a task }\end{array}$ & 2 & 11.76 \\
\hline Financial problem & 2 & 11.76 \\
\hline Lazy attitude & 2 & 11.76 \\
\hline $\begin{array}{l}\text { Being playful and not focus } \\
\text { in study }\end{array}$ & 2 & 11.76 \\
\hline Poor time management & 2 & 11.76 \\
\hline $\begin{array}{l}\text { Copy the work from other } \\
\text { students without study the } \\
\text { contents }\end{array}$ & 1 & 5.88 \\
\hline Poor learning style & 1 & 5.88 \\
\hline $\begin{array}{l}\text { Stay in different colleges } \\
\text { from classmates }\end{array}$ & 1 & 5.88 \\
\hline Bad peer influences & 1 & 5.88 \\
\hline \multicolumn{1}{|c|}{ Total } & $\mathbf{1 7}$ & $\mathbf{1 0 0}$ \\
\hline
\end{tabular}

Table 6 shows positive factors affecting academic achievement of students gained CGPA between 3.00 and 3.49. Based on the data obtained, most dominant factors were complete assignment given by the lecturer and proper time management which each of them holds 17.65 percent. The following factors that valued by 11.76 percent were strong determination to success, a good intention to study and study group among friends. In addition, effective study plan, healthy competition among classmates and parents 
support in education are 5.88 percent. Last but not least, stable financial and do revision and final questions before examination also valued by 5.88 percent.

Table 6: Positive factors affecting academic achievement of students gained CGPA between 3.00 and 3.49

\begin{tabular}{|l|c|c|}
\hline \multicolumn{1}{|c|}{ Response } & Number & Percentage \\
\hline $\begin{array}{l}\text { Complete assignment } \\
\text { given by the lecturers }\end{array}$ & 3 & 17.65 \\
\hline Proper time management & 3 & 17.65 \\
\hline $\begin{array}{l}\text { Strong determination to } \\
\text { success }\end{array}$ & 2 & 11.76 \\
\hline A good intention in study & 2 & 11.76 \\
\hline $\begin{array}{l}\text { Study group among } \\
\text { friends }\end{array}$ & 2 & 11.76 \\
\hline Effective study plan & 1 & 5.88 \\
\hline $\begin{array}{l}\text { Healthy competition } \\
\text { among classmates }\end{array}$ & 1 & 5.88 \\
\hline $\begin{array}{l}\text { Parents support in } \\
\text { education }\end{array}$ & 1 & 5.88 \\
\hline Stable financial & 1 & 5.88 \\
\hline $\begin{array}{l}\text { Do revision and final } \\
\text { questions before } \\
\text { examination }\end{array}$ & $\mathbf{1 7}$ & $\mathbf{1 0 0}$ \\
\hline \multicolumn{1}{|c|}{ Total } & & 5.88 \\
\hline
\end{tabular}

Other than that, Table 7 shows positive factors affecting academic achievement of students gained CGPA above 3.49. The data was collected from 17 respondents. We found that the primary factor was strong determination to success which is 30.00 percent followed by parents' support in education which is 20.00 percent. Plus, focus in class so that less time is required to do revision and proper time management are 10.00 percent each. Three other factors which also valued by 10.00 percent were study group among friends, involvement in out-of-class activities make study time more efficient and surrounded by supportive friends.

Table 7: Positive factors affecting academic achievement of students gained CGPA above 3.49

\begin{tabular}{|l|c|c|}
\hline \multicolumn{1}{|c|}{ Response } & Number & Percentage \\
\hline $\begin{array}{l}\text { Strong determination to } \\
\text { success }\end{array}$ & 3 & 30.00 \\
\hline Parents support in education & 2 & 20.00 \\
\hline $\begin{array}{l}\text { Focus in class so that less } \\
\text { time is required to do } \\
\text { revision }\end{array}$ & 1 & 10.00 \\
\hline Proper time management & 1 & 10.00 \\
\hline Study group among friends & 1 & 10.00 \\
\hline
\end{tabular}

\begin{tabular}{|l|c|c|}
\hline $\begin{array}{l}\text { Involvement in out-of-class } \\
\text { activities make study time } \\
\text { more efficient }\end{array}$ & 1 & 10.00 \\
\hline $\begin{array}{l}\text { Surrounded by supportive } \\
\text { friends }\end{array}$ & 1 & 10.00 \\
\hline Total & $\mathbf{1 0}$ & $\mathbf{1 0 0}$ \\
\hline
\end{tabular}

\section{CONCLUSION}

The aim of this study to identify factors that influence the achievement of student academic performance among College Students' Committee of KTDI, UTM. The results show that strong determination to success, proper time management completing assignment given are the most important factors in determining student achievement in university. Some efforts made such as college students' committee meetings with High Council of College Students' Committee and Fellow Council of KTDI, study on development of academic performance and also counselling session regarding academic review of college students' committee. College Students' Committee also has conduct a programme which was 'A Synergised Community Programme: ICT in English and Augmented Reality for Rural Learners (iCARE INSPIRE-ASPIRE) that focus on academic. These kinds of activities not only discuss on academic matters but also foster the relationship between the students and academic staff.

There are some limitations for this study, this study focuses only on college students' committee KTDI and this cannot be generalized by other UTM students. In the future, this study can be extended to other colleges in UTM Johor Bahru such as Kolej Tun Hussein Onn, Kolej Tun Razak, Kolej Rahman Putra., Kolej Tuanku Canselor, Kolej Tun Fatimah, Kolej Perdana, Kolej 9\&10, Kolej Datin Sri Endon, and Kolej Dato' Onn Faafar. Other studies such as comparative studies between college students' committee and non-college students' committee students can also be made to identify significant differences between the two groups with the achievement of student academic performance. The results of this study are expected to be used to identify factors that may affect the achievement of academic performance at university level.

\section{ACKNOWLEDGMENT}

We would like to thank Kolej Tun Dr. Ismail (KTDI) and Universiti Teknologi Malaysia (UTM) for the financial support.

\section{REFERENCES}

[1]Abdullah, A., Mesir, B. and Mohamad, A.M. (2006) Faktor-faktor Yang Menyumbang kepada Kecemerlangan Akademik Pelajar di Universiti Teknologi Malaysia. Proceedings of the National Student Development Conference 2006 (NASDEC 
2006). August 8-9. Skudai, Johor: SPACE and IPF, 3248.

[2]Ali, M. and Noordin, S. (2010) Hubungan Antara Kemahiran Berfikir Kritis Dengan Pencapaian Akademik Dalam Kalangan Pelajar Fakulti Pendidikan Universiti Teknologi Malaysia. Jurnal Teknologi, 52, 45-55.

[3]Amir Razali, M.Z.F., Salleh, M.S., and Yusoff, M.Z. (2006) Faktor-faktor Yang Mempengaruhi Pencapaian Pelajar Cemerlang di Universiti Teknologi MARA (UiTM) Kelantan bagi Semester Disember 2005 - Mei 2006 Proceedings of the National Student Development Conference 2006 (NASDEC 2006). August 8-9. Skudai, Johor: SPACE and IPF, 153-163.

[4]Garry Kuan, Nurzulaikha Abdullah, Yee Cheng Kueh, Mohd Ismail, Mohd Nazri Shafei and Tony Morris (2019) Co-Curricular Activities and Motives for Participating in Physical Activity among Health Sciences Students at Universiti Sains Malaysia, Malaysia. The Malaysian Journal of Medical Sciences, 26(1), 138-146.

[5]Ilias, K., Abdul Rahman, R., Md Nor, M. and Saidon, N.A. (2010) Pengaruh Gaya Pembelajaran Terhadap Motivasi dan Pencapaian Akademik Pelajar Pra Ijazah Sarjana Muda Perguruan Institut Pendidikan Guru Kampus Ipoh. Jurnal Penyelidikan Dedikasi. 2, 141-153.

[6]Jumardi Budiman and Juliahir Barata (2018) Pengaruh Gaya Kepemimpinan Terhadap Pencapaian Akreditasi Institusi Perguruan Tinggi Swasta Di Kalimantan Barat. JURKAMI: Jurnal Pendidikan Ekonomi, Vol 3, No 2.

[7]Kamaruddin, M.I. and Mohamad, A. (2011) Kajian Gaya Pembelajaran Dalam Kalangan Pelajar UTM. Journal Educational Psychology and Counseling, 2, 5177.

[8]Mesir, B., Mohd Yatim, J., Abd Aziz, A., Jamal, M.H. and Zainal Abideen, M. (2006) Gaya Hidup Pelajar Cemerlang dalam Persekitaran Kampus. Proceedings of the National Student Development Conference 2006 (NASDEC 2006). August 8-9. Skudai, Johor: SPACE and IPF, 665-674.

[9]Salleh, M.S., Amir Razali, M.Z.F. and Yusoff, M.Z. (2006) Faktor-faktor Yang Mempengaruhi Pencapaian Akademik Yang Rendah di kalangan Mahasiswa/i Universiti Teknologi MARA (UiTM) Kelantan bagi Semester Disember 2005 - Mei 2006. Proceedings of the National Student Development Conference 2006 (NASDEC 2006). August 8-9. Skudai, Johor: SPACE and IPF, 141-152. 